\title{
Genetics of CM-proteins (A-hordeins) in barley
}

\author{
G. Salcedo, P. Fra-Mon, J. L. Molina-Cano', C. Aragoncillo and F. García-Olmedo \\ Departamento de Bioquímica, E.T.S. Ingenieros Agrónomos-UPM, Madrid-3, Spain \\ ${ }^{1}$ La Cruz del Campo, S.A., Department of Barley Breeding, Sevilla, Spain
}

Summary. The CM-proteins, which are the main components of the A-hordeins, include four previously described proteins (CMa-1, CMb-1, CMc-1, CMd-1), plus a new one, CMe-1, which has been tentatively included in this group on the basis of its solubility properties and electrophoretic mobility. The variability of the five proteins has been investigated among 38 Hordeum vulgare cultivars and $17 \mathrm{H}$. spontaneum accessions. Proteins CMa-1, CMc-1 and CMd-1 were invariant within the cultivated species; CMd was also invariant in the wild one. The inheritance of variants CMb-1/CMb-2 and CMe-1/CMe-2,2' was studied in a cross $H$. spontaneum $\times H$. vulgare. The first two proteins were inherited as codominantly expressed allelic variations of a single mendelian gene. Components CMe-2,2' were jointly inherited and codominantly expressed with respect to CMe-1. Gene $C M b$ and gene(s) $C M e$ were found to be unlinked. The chromosomal locations of genes encoding CM-proteins were investigated using wheat-barley addition lines. Genes $C M a$ and $C M C$ were associated with chromosome 1 , and genes $C M b$ and $C M d$ with chromosome 4 . These gene locations further support the proposed homoeology of chromosomes 1 and 4 of barley with chromosomes groups 7 and 4 of wheat, respectively. Gene(s) $C M e$ has been assigned to chromosome 3 of barley. The accumulation of protein CMe-l is totally blocked in the "high lysine" mutant Riso 1508 and partially so in the high lysine barley Hiproly.

Key words: Hordeins - Genes encoding proteins Homeology of chromosomes - Lysine - Barley Hordeum

\section{Introduction}

Hordeins, the prolamins of barley endosperm, can be classified into the A, B, C, and D fractions according to their increasing apparent molecular weights (Køie et al. 1976; Miflin et al. 1983).

Studies of the genetic control of these proteins have been actively pursued because of their relevance in connection with the nutritional improvement of this important crop (for a review, see Shewry and Miflin 1982). Solari and Favret (1971) located a number of loci controlting hordein polypeptides in a segment of chromosome 5 . More recent work (Oram et al. 1975; Shewry et al. 1978, 1980; Netsvetaev 1978; Sozinov et al. 1978; Doll and Brown 1979; Jensen et al. 1980) has led to the characterization of two complex loci, Horl and Hor2, which encode $\mathrm{C}$ and $\mathrm{B}$-hordeins, respectively, and are located in the short arm of chromosome 5. Lawrence and Shepherd (1981), using wheat-barley addition and translocation lines, located the gene for D-hordein in the long arm of the same chromosome, a finding which has been fully confirmed with the characterization of the Hor3 locus by Shewry et al. (1983). In contrast with the abundant information available on the genetics of B, C, and D-hordeins, there has been no report on the genetic control of A-hordeins.

At least two subgroups of proteins have been described within the A-hordein fraction, namely the CM-proteins, which include the main components, and the low-molecular-weight hordeins (Salcedo et al. 1980; Aragoncillo et al. 1981; Salcedo et al. 1982; PazAres et al. $1983 \mathrm{a}$ ). The CM-proteins are salt-soluble, hydrophobic proteins that can be extracted with chloroform:methanol mixtures and with aqueous alcohols and seem to be present in all cereal species investigated (Salcedo et al. 1980; Paz-Ares et al. 1983 a). The four barley CM-proteins that have been purified and characterized (CMa, CMb, CMc, CMd; designated here CMa-1, CMb-1, CMc-1, CMd-1) have been found to be homologous to the wheat $\mathrm{CM}$-proteins by amino acid analysis and immunochemical methods (Salcedo et al. 
1982; Paz-Ares et al. 1983 a). They seem to be located in the cytosol, but are synthesized by membrane-bound polysomes as precursors of higher molecular weight. which undergo co-translational processing into the mature proteins (Paz-Ares et al. 1983 b). We now report on the following aspects of the genetics of barley CMproteins: i) Variability of the four previously described components, and of a newly described one (CMe-1), among Hordeum vulgare cultivars and $H$. spontaneum accessions. ii) Inheritance of some variant in a cross $H$. spontaneum $\times H$. vulgare. iii) Chromosomal locations of structural genes, using barley-wheat addition lines. iv) Effect of the "high lysine" mutations of Riso-1508 and Hiproly on protein CMe-1.

\section{Materials and methods}

\section{Genetic stocks}

The survey of $H$. vulgare cultivars and $H$. spontaneum accessions was carried out using samples from the collection of $\mathrm{La}$ Cruz del Campo, S.A., Malting and Brewing Company (Sevilla, Spain). We have used the following cultivars of H. vulgare: Lupe. Almunia, Albacete, Berta, Cerro. Hatif de Grignon, Precoce Lepeuple, Monlon, Astrix, Hop, Troubadour, Porthos, Beka, Zephyr, Betzes, Printa, Spratt Archer, Logra, Donaria, Ingrid, Rika, Karri and Bomi. We have also studied 12 different autoctonous land races or bulk selections of $H$. vulgare collected in Morocco. The number and origin of $H$. spontaneum accessions used were as follows: 8 from Morocco, 2 from Israel, 2 from Lybia, 4 from Afghanistan and 1 from Irak.

Crosses of $H$. spontaneum no. 8 from Morocco and $H . v u l$. gare cv. Troubadour were carried out at Sevilla (Spain). Cultivar Bomi, its high lysine mutant Risø-1508. Hiproly barley and its sister line CI4362 were obtained from Dr. A. Hagberg (Svaløf, Sweden). Disomic addition lines of chromosomes $1.2,3,4,6$ and 7 of Betzes barley on a wheat cv. Chinese Spring background, obtained by Islam et al. (1978), were the kind gift of Dr. K. W. Shepherd (Adelaide, Australia).

\section{Protein extraction}

Kernels (40-50 mg) were crushed with a hammer between two metal plates and then transferred to a smafl tube. Lipids were extracted with petroleum ether (b.p. $40^{\circ}-70^{\circ} \mathrm{C} ; 10 \mathrm{v} / \mathrm{w} ;$ I h at room temperature). The extraction with chloroform: methanol (CM) $2: 1(\mathrm{v} / \mathrm{v})$ was carried out twice at room temperature $(10 \mathrm{v} / \mathrm{w}, \mathrm{I} \mathrm{h})$, and the solvent vacuum-evaporated. The $0.5 \mathrm{M}$ $\mathrm{NaCl}$ extraction was performed at $4{ }^{\circ} \mathrm{C}(2 \times 10 \mathrm{v} / \mathrm{w}$; I h $)$; after centrifugation, supernatants were precipitated with trichloroacetic acid (12.5\% final concentration), washed with acetone and vacuum-dried.

The fraction under 25,000 molecular weight of the crude CM extract was obtained according to Salcedo et al. (1980).

\section{Two-dimensional gel electrophoresis}

The survey of crude $\mathrm{CM}$ extracts from $H$. vulgare cultivars, $H$. spontaneum accessions and $\mathrm{F}_{2}$ kernels was performed essentially as follows: the first dimension was a $\mathrm{pH}$ gradient electrophoresis on preformed $\mathrm{pH}$ gradients (ampholines $\mathrm{pH}$ $5-8$ or $3-10 ; 5 \%$ polyacrylamide; $2 \mathrm{~mm} \times 7 \mathrm{~mm}$ columns) at
$67 \mathrm{~V} \mathrm{~cm}^{-1}$ for 2 or $3 \mathrm{~h}$. Samples were inserted at the acid end. Starch-gel electrophoresis was used for the second dimension $(0.1 \mathrm{M}$ aluminium lactate buffer, $\mathrm{pH} 3.2,3 \mathrm{M}$ urea; $1 \mathrm{~mm}$ $\times 10 \mathrm{~cm} \times 28 \mathrm{~cm}$ slabs; $4 \mathrm{~h}$ at $20 \mathrm{~V} \mathrm{~cm}^{-1}$ and $5^{\circ} \mathrm{C}$ ). Gels were stained with $0.05 \%$ nigrosine in methanol-water-acetic acid $5: 5: 1$, by vol) for $16 \mathrm{~h}$.

Wheat-barley addition lines were analyzed by a similar method, except that ampholines $\mathrm{pH} 4-9$ and $2 \times 140 \mathrm{~mm}$ columns were used in the first dimension. These genelic slocks were also examined by a second procedure in which equilibrium isoelectrofocusing ( $\mathbf{p H} 4-9$ ) was used in the first dimension, and the second dimension as described above.

Quantitation of protein CMe-1 in Hiproly and in Cl4362 was done by densitometry of stained gels at $620 \mathrm{~nm}$ in a Joyce and Loebl densitometer.

\section{Results}

\section{Variability of CM-proteins in Hordeum vulgare and $H$. spontaneum}

A limited survey of $H$. vulgare cultivars and $H$. spontaneum accessions was carried out to assess the genetic variability of CM-proteins. These proteins were analyzed by two-dimensional $\mathrm{pH}$-gradient polyacrylamide

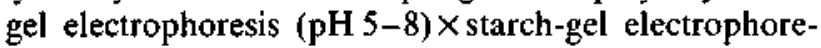
sis ( $\mathrm{pH}$ 3.2) of crude chloroform:methanol (CM) extracts. A wider $\mathrm{pH}$ range $(\mathrm{pH} 3-10)$ and shorter times in the first dimension were also used to check that no other proteins with higher isoelectric points were being excluded from the basic end of the gel. The previously described CM-proteins (CMa-1, CMb-1, $\mathrm{CMc}-1, \mathrm{CMd}-1)$ present in the fraction under 25,000 molecular weight, obtained from the crude $\mathrm{CM}$-extract of $H$. vulgare cv. Zephyr by gel filtration, are shown in Fig. $1 \mathrm{~A}$, whereas Fig. $1 \mathrm{~B}$ shows the two-dimensional map of the crude CM-extract. which includes additional components. Those identified with arrows are salt soluble proteins whose residual appearance in the CM-extract is not reproducible. The solubility properties of the map component provisionally designated CMe-1 and its electrophoretic mobility at $\mathrm{pH} 3.2$ are similar to those of the previously described CMproteins. Its absence from the fraction under 25,000 molecular weight might be due to a higher molecular weight or to aggregation during dialysis and gel filtration. Our previous failure to detect $\mathrm{CMe}-1$ in crude CM-extracts was due to the use of equilibrium isoelectrofocusing in the first dimension, which probably led to the exclusion of this protein. It should also be pointed out that the $\mathrm{CMe}-1$ spot seems to split into two closely-migrating ones in some electrophoretic runs. The purification and further characterization of this component is being pursued at present to clarify these questions and to ascertain its possible structural relationship with the other CM-proteins. A composite diagram showing the five $\mathrm{CM}$-proteins from the standard phenotype of cultivar Zephyr (CMa-1, CMb-1, 

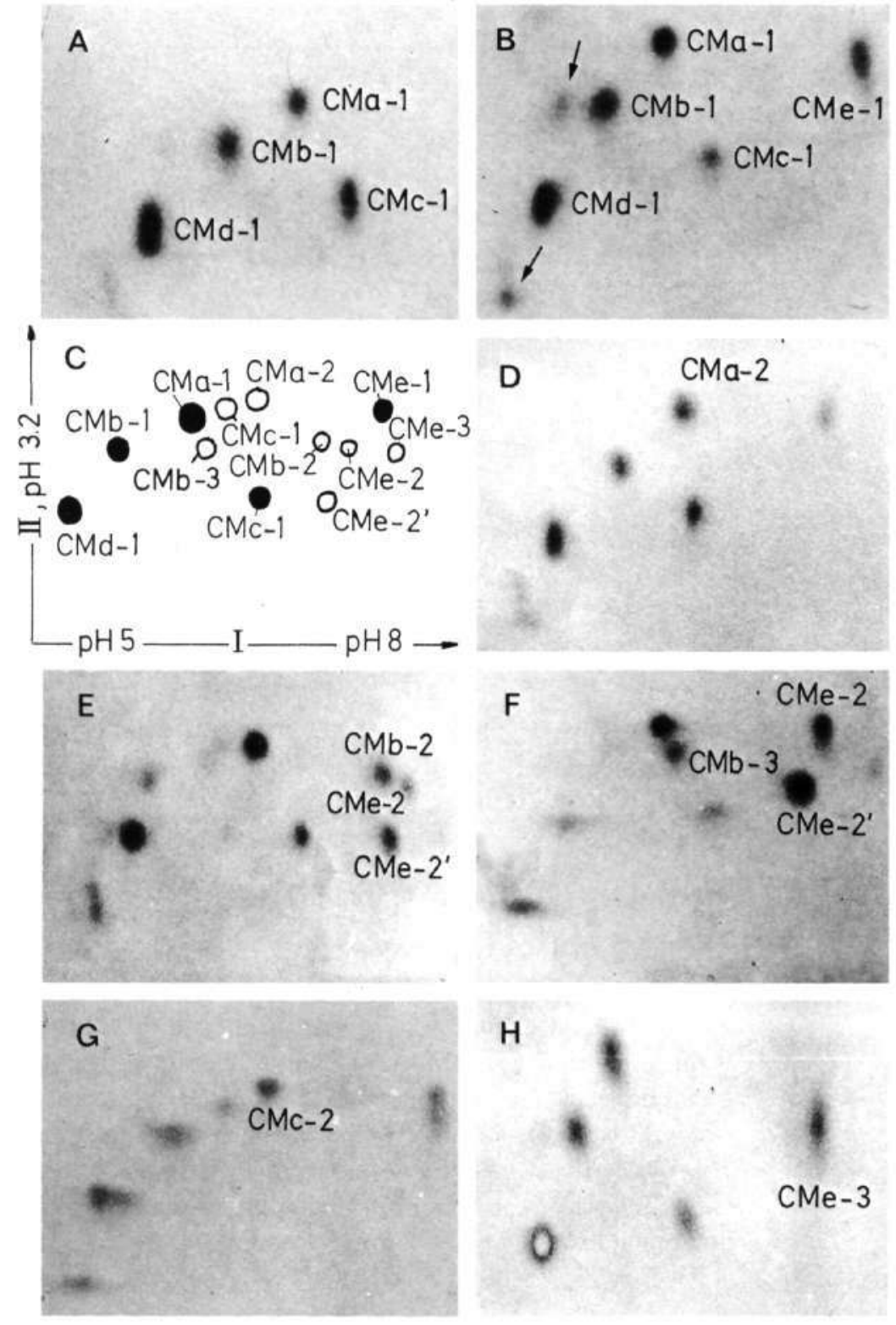
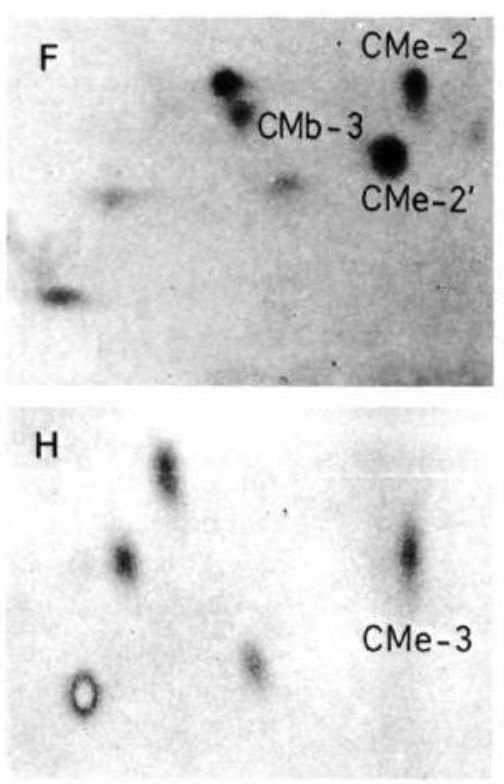

Fig. 1A-H. Fractionation by combined $\mathrm{pH}$ gradient (5-8) polyacrylamide-gel electrophoresis $\times$ starch-gel electrophoresis $(\mathrm{pH} 3.2)$. of $\mathrm{CM}$-proteins from Hordeum vulgare and H. spontaneum. A Fraction of mol. wt. $<25,000$ obtained by gel filtration of the crude CMextract of H. vulgare cv. Zephyr. B Crude extract from the same cultivar (standard phenotype). C Composite diagram showing relative positions in the two-dimensional map and designations of all observed variants. D-H Two-dimensional gels of crude extracts from different $H$. vulgare cultivars and $H$. spontaneum accessions, showing variants $C M a-2 ; C M b-2$ and $C M e-2,2^{\prime} ; C M b-3$ and $\mathrm{CMe}-2,2^{\prime} ; \mathrm{CMc}-2 ;$ and $\mathrm{CMe}-3$, respectively. Only the relevant parts of the gels are shown
CMc-1, CMd-1, CMe-1) and all their variants found in the survey is represented in Fig. 1C. The relative position of each variant in the diagram was checked by electrophoresis of a mixture of the variant and the standard phenotype or, when necessary, of a mixture of two variant phenotypes. The assignment of a new component as variant of a given standard protein was based on their alternative appearance in the samples surveyed and, in the case of those appearing at higher frequencies (CMb-2, CMe-2,2'), on the study of their inheritance in appropriate crosses (vide infra). Representative phenotypes are shown in Fig. 1D-H and all the observed phenotypes are listed in Table 1, together with the number of samples of $H$. vulgare and $H$. spontaneum with each phenotype and each variant. It should be pointed out that $\mathrm{CMb}-2$ and $\mathrm{CMe}-2,2^{\prime}$ are essentially restricted to samples of $H$. vulgare land races and H. spontaneum accessions with different morphological appearances collected in Morocco (MolinaCano et al. 1982). Outside Morocco, CMb-2 has been found in four Spanish cultivars selected out of different autoctonous land races (Almunia, Albacete, Berta and Cerro), and in the French cultivar Hatif de Grignon and some of its derivatives, whereas $\mathrm{CMe}-2,2^{\prime}$ has only been found in cv. Hatif de Grignon and all its derivatives included in our survey.

\section{Inheritance of $C M$-proteins in a cross of $H$. spontaneum $\times H$. vulgare}

A cross was carried out between $H$. spontaneum no. 8, a Moroccan accession which has the phenotype CMa-1, CMb-2, CMc-1, CMd-1, CMe-2,2' (Fig. 1E), and $H$. vulgare cv. Troubadour, which has the standard phenotype (Fig. 1B). As expected from the survey data, 
Table 1. Variability of CM-protein in Hordeum vulgare and H. spontaneum *

\begin{tabular}{|c|c|c|c|c|c|}
\hline \multirow{2}{*}{$\begin{array}{l}\text { Phenotype } \\
\text { (CM-proteins) }\end{array}$} & \multicolumn{2}{|c|}{ No. of samples } & \multirow{2}{*}{$\begin{array}{l}\text { Variant } \\
\text { protein }\end{array}$} & \multicolumn{2}{|c|}{ No. of samples } \\
\hline & H. vulgare & H. spontaneum & & H. vulgare & H. spontaneum \\
\hline$a-1 b-1 c-1$ d-1 e-1 & 15 & 2 & $\begin{array}{l}a-1 \\
a-2\end{array}$ & $\begin{array}{r}38 \\
0\end{array}$ & $\begin{array}{r}13 \\
4\end{array}$ \\
\hline$a-2$ b-1 c-1 d-1 e-1 & - & 4 & & & \\
\hline$a-1 b-2 c-1$ d-1 e-l & 5 & - & $\begin{array}{l}\text { b-1 } \\
b-2 \\
b-3\end{array}$ & $\begin{array}{r}30 \\
7 \\
1\end{array}$ & $\begin{array}{r}15 \\
1 \\
1\end{array}$ \\
\hline$a-1 b-3 c-1 d-1$ e-1 & 1 & 1. & & & \\
\hline $\mathrm{a}-1 \mathrm{~b}-1 \mathrm{c}-2 \mathrm{~d}-1 \mathrm{e}-1$ & - & 1 & $\begin{array}{c}c-1 \\
c-2\end{array}$ & $\begin{array}{r}38 \\
0\end{array}$ & $\begin{array}{r}16 \\
1\end{array}$ \\
\hline $\mathrm{a}-1 \mathrm{~b}-1 \mathrm{c}-1 \mathrm{~d}-1 \mathrm{e}-2,2$ & 13 & 6 & & & \\
\hline a-1 b-1 c-1 d-1 e-3 & - & 2 & d-1 & 38 & 17 \\
\hline $\begin{array}{l}\text { a-1 } b-2 \mathrm{c}-1 \mathrm{~d}-1 e-2,2^{\prime} \\
\text { a-1 } b-3 \mathrm{c}-1 \mathrm{~d}-1 e-2,2^{\prime}\end{array}$ & 2 & 1 & $\begin{array}{l}e-1 \\
e-2,2 \\
e-3\end{array}$ & $\begin{array}{r}21 \\
17 \\
0\end{array}$ & $\begin{array}{l}8 \\
7 \\
2\end{array}$ \\
\hline
\end{tabular}

- Total numbers of samples were $38 \mathrm{H}$. vulgare and $17 \mathrm{H}$. spontaneum

- Variant proteins with respect to the standard phenotype listed in the first place are in italic

CMb-1 and CMb-2 were inherited as allelic variants associated to a single mendelian locus with codominant expression (12 CMb-1:29 CMb-1 CMb-2:16 CMb-2; $1: 2: 1$ ratio, $\chi^{2}=0.578, P>70$ ). Components $\mathrm{CMe}-2,2^{\prime}$ were jointly inherited and were expressed codominantly with respect to CMe-1 (13 CMe-1:27 CMe-1 CMe-2,2' $: 17$ CMe-2,2'; $1: 2: 1$ ratio, $\chi^{2}=0.719, P>60$ ). No linkage was found between the $C M b$ and $C M e$ loci.

\section{Chromosomal locations of genes encoding CM-proteins}

The chromosomal assignment of genes encoding CMproteins was carried out by analysis of the wheat-barley addition lines obtained by Islam et al. (1978). These workers obtained disomic addition lines for six of the chromosomes of barley cv. Betzes on a wheat cv. Chinese Spring background. To insure the identification of the barley CM-proteins among the wheat ones, separations were carried out by the above described two-dimensional method and by a second procedure in which equilibrium isoelectrofocusing ( $\mathrm{pH} 4-9$ ) was used in the first dimension. Each line was analyzed by itself and as a mixture with barley cv. Betzes. Results are summarized in Fig. 2. Genes $C M a$ and $C M c$ were found to be located in chromosome 1 and genes $C M b$ and $C M d$ in chromosome 4 . In the case of the $C M e$ gene( $(s)$, a faint spot appeared at the CMe position in addition line 3 and in no other line, so it was tentatively concluded that this gene is located in chromosome 3 and that its expression is decreased in the wheat genetic background.

\section{$4 C M$-proteins in high-lysine mutants}

Mutant Risø-1508 obtained from cv. Bomi (Ingversen et al. 1973) was found to lack protein CMe-1, both when the extraction was carried out with chloroform: methanol $(2: 1, v / v)$ and when a more efficient but less selective extractant $(0.5 \mathrm{M} \mathrm{NaCl})$ was used (Fig. 3). Both procedures were also used to analyze Hiproly barley and its sister line CI4362. In this case protein $\mathrm{CMe}-1$ was present in the high lysine barley but at a much lower level $(\sim 35 \%)$.

\section{Discussion}

Our survey shows a low genetic variability for the CMproteins. No variation was found among $H$. vulgare cultivars for proteins CMa-1, CMc-1 and CMd-1, the latter being also invariant among $H$. spontaneum accessions. In contrast, $B$ and $C$ hordeins, which were analyzed by sodium dodecyl sulphate polyacrylamide electrophoresis in a number of the same samples from the two species, presented considerable variation (not shown), even though the separation method used, which essentially shows differences in apparent molecular weights, only detects a fraction of the variability detected by the method used for the CM-proteins, which detects differences in isoelectric points $(\mathrm{pH}$ gradient electrophoresis) and differences in the net charge of the protein at acid $\mathrm{pH}$ (electrophoresis at $\mathrm{pH} 3.2$ ). High variability for $\mathrm{B}$ and $\mathrm{C}$-hordeins has 

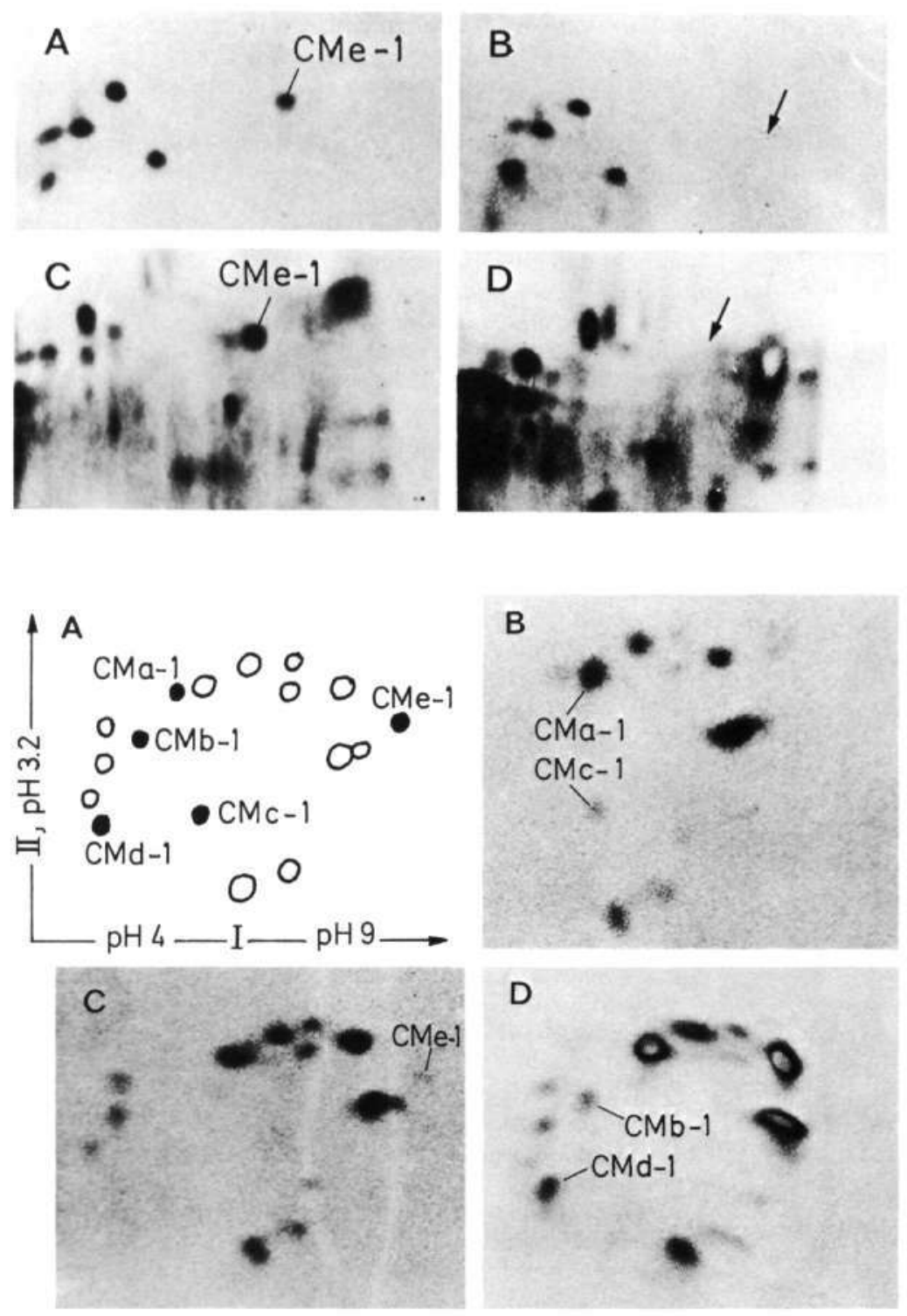

Fig. 2A-D. Analysis of protein $\mathrm{CMe}-1$ in $H$. vulgare cv. Bomi $(\mathbf{A}, \mathbf{C})$ and its "high lysine" mutant Risø 1508 (B, D), extracted with chloroform:methanol, 2:1, v/v (A, B), and with $0.5 \mathrm{M}$ $\mathrm{NaCl}$ (C, D). Fractionation was carried out as indicated in Fig. 1

Fig. 3A-D. Analysis by combined $\mathrm{pH}$ gradient (4-9) polyacrylamide-gel electrophoresis $\times$ starch-gel electrophoresis ( $\mathrm{pH} 3.2$ ) of CMproteins in wheat-barley disomic addition lines. A Diagram showing CM-proteins from a mixture of wheat and barley (open spots correspond to wheat). B-D Two-dimensional gels corresponding to addition lines 1,3 , and 4 , respectively been previously reported by other workers (Doll and Brown 1979; Shewry et al. 1979). The low genetic variability of CM-proteins in barley is in agreement with that observed for the same proteins in wheat, where no variants were found in an extensive survey of Triticum aestivum and T. turgidum samples, with the exception of variant $\mathrm{CM}^{\prime}$ of protein $\mathrm{CM} 3$, which was found in only two closely related $T$. turgidum cultivars (García-Olmedo and García-Faure 1969; RodriguezLoperena et al. 1975; Salcedo et al. 1978). The fact that $\mathrm{CMe}-2,2^{\prime}$ are present in 7 out of $8 \mathrm{H}$. spontaneum samples and in 11 out of $12 \mathrm{H}$. vulgare samples from Morocco indicates either intense introgression or even a possible domestication event in that area. The appearance of this variant and of $\mathrm{CMb}-2$ outside Morocco is restricted to cultivars in Spain and France derived from land races that could plausibly have a North African origin. A full discussion of this problem will be presented elsewhere (Molina-Cano et al., in preparation).

Isozyme and endosperm protein markers have been associated with chromosomes 1, 2, 3, 4, 5, and 6 of barley (Hart et al. 1980; Lawrence and Shepherd 1981; Powling etal. 1981). These gene locations have provided evidence of homoeology between chromosomes $1,4,5$, and 6 of barley and chromosome groups $7,4,1$, and 6 of wheat, respectively. Our present findings provide new biochemical barley chromosome markers. Furthermore, the chromosomal locations of genes $C M a, C M b, C M c$, and $C M d$ reinforce the previous conclusions concerning the homeology of chromosomes 1 and 4 of barley with chromosome groups 7 and 4 of wheat. Indeed genes encoding CM- 
proteins in wheat have been located in chromosomes of groups 7 and 4 (García-Olmedo and Carbonero 1970; Aragoncillo et al. 1975).

The chemical characterization and the immunochemical comparison of CM-proteins purified from wheat and barley indicate a close relationship between the proteins from the two sources (Salcedo et al. 1982; Paz-Ares et al. 1983 a). In particular, CMd from bartey and $\mathrm{CM} 3$ from wheat have very similar molecular weights and amino acid composition, are, in each case, the only proteins extracted with the $7: 1(\mathrm{v} / \mathrm{v})$ mixture of chloroform: methanol and show complete antigenic identity. Accordingly, gene $C M 3$ is located in chromosome $4 \mathrm{~A}$ of wheat and gene $C M d$ in chromosome 4 of barley. The fact that gene(s) encoding protein $\mathrm{CMe}-1$ are not located in chromosomes 1 and 4 suggests that, in spite of its similar solubility properties, this protein is probably non-homologous to the previously purified barley and wheat CM-proteins.

Protein CMe is also different from the other four barley $\mathrm{CM}$-proteins in that its synthesis is specifically blocked by the high lysine mutation in Rise 1508 and drastically decreased in Hiproly barley as compared with its sister line CI4362. It has been reported that B and C-hordeins are markedly decreased in Risø 1508 and to a lesser extent in Hiproly, while the salt soluble proteins are increased in both (see Miflin and Shewry 1979). Rhodes and Gill (1980) reported a salt-soluble component that seemed to be absent in Rise 1508, and Hejgaard (1982) found that a salt-soluble protein, designated protein $Z$, was at a lower level in Riso 1508 but was greatly increased in Hiproly. To our knowledge, CMe-1 is the first salt-soluble protein to be described whose accumulation is totally or partially blocked both in Rise 1508 and Hiproly.

Acknowledgements. We gratefully acknowledge advice and the gift of the wheat-barley addition lines from Dr. K.W. Shepherd, and technical help from J. Garcia-Guijarro.

\section{References}

Aragoncillo C, Rodriguez-Loperena MA, Carbonero P, Gascia-Olmedo F (1975) Chromosomal control of nongliadin proteins from the $70 \%$ ethanol extract of wheat endosperm. Theor Appl Genet 45:322-326

Aragoncillo C. Sanchez-Monge R, Salcedo G (1981) Two groups of low molecular weight hydrophobic proteins from barley endosperm. J Exp Bot 32: 1279-1286

Doll H. Brown AD (1979) Hordein variation in wild (H. spontaneum) and cultivated (H.vulgare) barley. Can J Genet Cytol 21:391-404

García-Olmedo F, Carbonero P (1970) Homeologous proteins synthesis controlled by homeologous chromosomes in wheat. Phytochemistry 9:1495-1497

Garcia-Olmedo F, Garcia-Faure R (1969) A new method for the estimation of common wheat (Triticum aestivum L.) in pasta products. Lebensm-Wiss + Technol 2:94-96
Hart GE, Islam AKMR, Shepherd KM (1980) Use of isozymes as chromosome markers in the isolation and characteriza. tion of wheat-barley chromosome addition lines. Genet Res $36: 311-325$

Hejgaard J (1982) Purification and properties of protein Z, a major albumin of barley endosperm. Physiol Plant 54: 174- 182

Ingversen J. Keie B. Doll H (1973) Induced seed protein mutant of barley. Experientia 29:115I-1152

Islam AKMR, Shepherd KW, Sparrow DHB (1978) Production and characterization of wheat-barley addition lines. 5 th Int Wheat Genet Symp, pp 365-371

Jensen J. Jorgensen JH, Jensen HP, Giese H, Doll H (1980) Linkage of the hordein loci Hor-l and Hor-2 with the powdery mildew resistance loci $M / k$ and $M / a$ on barley chromosome 5. Theor Appl Genet 58:27-37

Koie B. Ingversen J, Andersen AJ, Doll H, Eggum BO (1976) Composition and nutritional quality of barley protein. In: Evaluation of seed protein alterations by mutation breeding. IAEA pp 55-6I

Lawrence GJ, Shepherd KW (1981) Chromosomal location of genes controlling seed proteins in species related to wheat. Theor Appl Genet 59:25-31

Miflin BJ, Field JM, Shewry PR (1983) Cereal storage proteins and their effects on technological properties. In: Daussant J, Mossé J, Vaughan J. (eds) Seed proteins. Academic Press, London New York, pp 253-319

Miflin BJ, Shewry PR (1979) The synthesis of proteins in normal and high lysine barley seeds. In: Laidman D. Wyn Jones RG (eds) Rec Adv Biochem Cereals. Academic Press, London New York, pp 234-273

Molina-Cano JL, Gomez-Campo C, Conde J (1982) Hordeum spontaneum c. Koch as a weed of barley fields in Morocco. Z Pflanzenzücht 88: 161-167

Netsvetaev VP (1978) Mapping of loci $\mathrm{Hrd}$ in chromosome 5 of barley with the help of reciprocal translocations. Biologischeskie Osmovy Ratseonalnogo Ispolzovaniya i Jivotuogo Rastitelnogo, p 145

Oram RN, Doll H, Køie B (1975) Genetics of two storage protein variants in barley. Hereditas $80: 53-58$

Paz-Ares J, Hernandez-Lucas C, Salcedo G, Aragoncillo C, Ponz F, García-Olmedo F (1983 a) The CM-proteins from cereal endosperm: immunochemical relationships. J Exp Bot 34:388-395

Paz-Ares J, Ponz F, Aragoncillo C. Hernandez-Lucas C, Salcedo G, Carbonero P, García-Olmedo F (1983 b) In vivo and in vitro synthesis of CM-proteins (A-hordeins) from barley (Hordeum vulgare L.). Planta 157:74-80

Powling A, Islam AKMR, Shepherd KW (1981) Isozymes in wheat-barley hybrid derivative lines. Biochem Genet 19: 237-254

Rhodes AP, Gill AA (1980) Fractionation and amino acid analysis of the salt-soluble protein fractions of normal and high-lysine barleys. J Sci Food Agric 31:467-473

Rodriguez-Loperena MA, Aragoncillo C, Carbonero P, García-Olmedo $F$ (1975) Heterogeneity of wheat endosperm proteolipids (CM proteins). Phytochemistry 14: 1219-1223

Salcedo G, Rodriguez-Loperena MA, Aragoncillo C (1978) Relationships among low MW hydrophobic proteins from wheat endosperm. Phytochemistry 17:1491-1494

Salcedo G, Sanchez-Monge R, Aragoncillo C (1982) The isolation and characterization of low molecular weight hydrophobic salt soluble proteins from barley. J Exp Bot 33: $1325-1331$

Salcedo G, Sanchez-Monge R, Argamenteria A, Aragoncillo C (1980) The A-hordeins as a group of salt soluble hydrophobic proteins. Plant Sci Lett 19:109-119 
Shewry PR, Faulks AJ, Pickering RA. Jones IT, Finch RA, Miflin BJ (1980) The genetic analysis of barley storage proteins. Heredity 44:383-389

Shewry PR. Finch RA, Parmar S, Franklin J, Miflin BJ (1983) Chromosomal location of Hor-3. a new locus governing storage proteins in barley. Heredity $50: 179-190$

Shewry PR, Miflin BJ (1982) Genes for the storage proteins of barley.Qual Plant Mater Veg 31:251-267

Shewry PR, Pratt HM, Faulks AJ, Parmar S, Miflin BJ (1979) The storage protein (hordein) polypeptide pattern of barley (Hordeum vulgare $\mathbf{L}$ ) in relation to varietal identi- fication and disease resistance. J Nat Inst Agric Bot (GB) 15:34-50

Shewry PR. Pratt HM, Finch RA, Miflin BJ (1978) Genetic analysis of hordein polypeptides from single seeds of barley. Heredity 40:463-466

Solari RM, Favret EA (1971) Polymorphism in endosperm proteins of barley and its genetic control. In: Nilan R (ed) Barley genetics, vol Il. Washington University Press. PP 23-3i

Sozinov AA, Netsvetaev VP, Grigoryan EM, Obraztsov IS (1978) Mapping of the Hrd loci in barley (Hordeum vulgare). Genetika 14:1610-1619 